\title{
Virus-like particles of potato leafroll virus as potential carrier system for nucleic acids ${ }^{\star}$
}

\author{
Elżbieta Sułuja, Ludmiła Strokowskaja, Włodzimierz Zagórski-Ostoja and \\ Andrzej Pałucha ${ }^{\bowtie}$
}

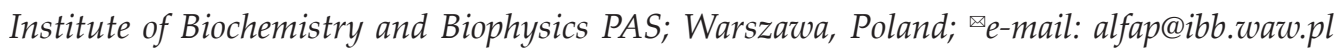

Received: 15 March, 2005; revised: 14 July, 2005; accepted: 28 July, 2005

available on-line: 15 September, 2005

\begin{abstract}
Potato leafroll virus is a member of the polerovirus genus. The isometric virion is formed by a coat protein encapsidating single-stranded, positive-sense, mono-partite genomic RNA with covalently attached viral protein at the $5^{\prime}$ end. The coat protein of the virus exists in two forms: i) a $23 \mathrm{kDa}$ protein, the product of the coat protein gene, and ii) a $78 \mathrm{kDa}$ protein, the product of the coat protein gene and an additional open reading frame expressed by read-through of the coat protein gene stop codon. The aim of this work was the expression of potato leafroll virus coat protein-based proteins that would be able to assemble into virus-like particles in insect cells. These modified particles were tested for their ability to encapsidate nucleic acids. Two types of N-terminally His-tagged coat protein constructs were used for the expression in insect cells: one, encoding a $23 \mathrm{kDa}$ protein with the C-terminal amino-acid sequence corresponding to the wild type coat protein and the second with additional clathrin binding domain at the C-terminus. The expression of these two proteins by a recombinant baculovirus was characterized by Western immunoblotting with antibodies directed against potato leafroll virus. The protection or putative encapsidation of nucleic acids by these two coat protein derivatives was shown by DNase I and RNase A protection assays.
\end{abstract}

Keywords: Virus-like particles, encapsidation

Virus-like particles formed by the structural elements of viruses have received considerable attention over the past two decades. When expressed in a suitable heterologous system, viral structural proteins involved in capsid or envelope formation often self-assemble into VLPs in the absence of other viral components usually required for virus assembly, such as multiple structural or non-structural proteins and viral genomes. The protein-protein interactions in VLPs are relatively strong and can result in the formation of stable structures. Depending on the nature of the viral protein, such structures can be modified on their surface in order to introduce foreign epitopes, and they may be used to encapsidate non-viral nucleic acids or small proteins.

Potato leafroll virus particles consist of a single-stranded positive sense RNA about $5.8 \mathrm{~kb}$ long encapsidated in the major coat protein of $23 \mathrm{kDa}$ (Mayo et al., 1989; van der Wilk et al., 1989). Se- quence analysis of a Polish isolate of PLRV (Palucha et al., 1994) confirmed the presence of several open reading frames. The viral $\mathrm{CP}$ gene is expressed in two forms: as a $23 \mathrm{kDa}$ protein and a $78 \mathrm{kDa}$ fusion protein after read-through of the stop codon during translation of the CP gene (Bahner et al., 1990).

The assembly of VLPs of PLRV in insect cells infected by a recombinant baculovirus containing the $\mathrm{CP}$ gene, modified at the $\mathrm{N}$-terminus by a His-tag (MHHHHHHGDDDDKDAMG), was previously reported (Lamb et al., 1996). The sedimentation coefficient of such VLPs in sucrose gradients was similar to that of viral particles, suggesting the presence of encapsidated nucleic acids. In our study we expressed two types of VLPs, one with the Cterminus of the $\mathrm{CP}$ corresponding to the wild type protein and the second with a clathrin binding domain attached to the end of the CP. Protection of small nucleic acids by the PLRV CP was shown in a DNase I and RNase A protection assay.

^Paper was presented at the International Review Conference on Biotechnology, Vienna, Austria, November 2004. Abbreviations: $\mathrm{BCIP}$, 5-bromo-4-chloro-3-indolyl-phosphate; $\mathrm{CP}$, coat protein; NBT, 4-nitro blue tetrazolium chloride; PBS, phosphate-buffered saline; PLRV, potato leafroll virus; VLPs, virus-like particles. 


\section{MATERIALS AND METHODS}

Materials. Appropriate fragments of the $\mathrm{CP}$ cDNA were amplified by PCR using one $5^{\prime}$ primer (h) and two $3^{\prime}$ primers (CP and $\mathrm{CPC}$ ). Primer h was $5^{\prime}$ ATGCATCACCATCACCATCACGGGGACGATGACG ATAAAGACGCCATGGGTATGAGTACGGTCGTGGTTAAAGG, primer CP was 5' AAGCTTCTATTTGG GGTTTTGCAAAG and primer CPc was 5' AAGCTTCTAATCCAGATCCAGCAGTTTGGGGTTTTGCAAAG. The initiation codon (primer $h$ ) and the complement of the termination codon (primers $\mathrm{CP}$ and $\mathrm{CPc}$ ) are in bold. The complement of the clathrin binding domain is in italics (primer $\mathrm{CPc}$ ). PCR products were cloned into pGEM-T Easy cloning system and then subcloned to the $\mathrm{pFastBac}^{\mathrm{TM}} 1$ vector in order to obtain plasmids $\mathrm{pFhCP}$ and $\mathrm{pF}$ hCPc suitable in construction of recombinant baculoviruses.

Purification and expression of recombinant baculoviruses. Using the Bac-to-Bac ${ }^{\circledR}$ system, purified DNA of donor plasmids $\mathrm{pFhCP}$ and $\mathrm{pFh}$ $\mathrm{CPC}$ was transformed into competent $\mathrm{DH} 10 \mathrm{Bac}^{\mathrm{TM}}$ Escherichia coli cells in order to obtain, after in vivo transposition, recombinant BhCP and BhCPc Bacmid DNA. Transfection of Spodoptera frugiperda (Sf9) cells and expression of particular recombinant virus was managed according to the manufacturer's protocol.

Fractionation and purification of VLPs. Insect cells expressing appropriate VLPs were incubated for 72 and $96 \mathrm{~h}$. Then, the cells were collected by centrifugation at 1000 r.p.m. for $10 \mathrm{~min}$ at $15^{\circ} \mathrm{C}$ from $25 \mathrm{ml}$ cultures and resuspended in $10 \mathrm{ml}$ of $0.1 \mathrm{M}$ sodium citrate, $\mathrm{pH} \mathrm{6}$, containing $0.4 \mathrm{M} \mathrm{NaCl}$. After vortexing for $10 \mathrm{~min}$ with glass beads, the extracts were centrifuged at 8000 r.p.m. for $15 \mathrm{~min}$ at $10^{\circ} \mathrm{C}$ (Sigma 3K30, 12158) and the supernatant fraction was additionally centrifuged for $10 \mathrm{~min}$ at 15000 r.p.m. at $10^{\circ} \mathrm{C}$. Particles were recovered from the final supernatant by centrifugation for $3 \mathrm{~h}$ at 45000 r.p.m. at $10^{\circ} \mathrm{C}$. Pellets were resuspended in $0.5 \mathrm{ml}$ of $10 \mathrm{mM}$ sodium phosphate, $\mathrm{pH} 7$.

Immunoblotting. Proteins were separated on $12 \%$ polyacrylamide/SDS gels and electroblotted onto Hybond-C membranes as described by Ausubel et al. (1987). Membranes were blocked for $4 \mathrm{~h}$ using $5 \%$ non-fat milk and $0.1 \%$ Tween 20 in PBS buffer at room temperature and then incubated for $1 \mathrm{~h}$ with anti-potato leafroll virus antibody conjugated with alkaline phosphatase (Boehringer Mannheim $\mathrm{GmbH}$ ) diluted in blocking buffer at $1 / 5000$. Blots were then washed in PBS and the alkaline phosphatase activity was developed using NBT/BCIP solution (Roche).

RNase $A$ and DNase I treatment. Purified protein extracts $(200 \mu \mathrm{l})$ carrying PLRV VLPs and extracts from insect cells infected with non-recombinant baculovirus were mixed with $200 \mu \mathrm{l}$ of $2 \times$ reaction mixture containing $40 \mathrm{mM}$ Tris/ $\mathrm{HCl}, \mathrm{pH}$
8.3, $4 \mathrm{mM} \mathrm{MgCl}_{2}, 20$ units of deoxyribonuclease I (Sigma, D5307) and $200 \mu \mathrm{g}$ of ribonuclease A (ICN, 193280). After incubation for $1 \mathrm{~h}$ at $37^{\circ} \mathrm{C}$ the remaining nucleic acids were extracted by vortexing with phenol and phenol:chloroform and precipitated by 2 vol. of ethanol after addition of $1 / 10$ vol. of $3 \mathrm{M}$ sodium acetate, $\mathrm{pH} 4.8$.

\section{RESULTS AND DISCUSSION}

To express in insect cells the coat protein of potato leafroll virus modified at the N-terminus, two recombinant baculoviruses were constructed. BhCP, which contain cDNA encoding the $\mathrm{CP}$ unmodified at the $\mathrm{C}$-terminus and $\mathrm{BhCPc}$ carrying cDNA with the gene modified by addition of a clathrin binding domain sequence. The modified constructs were obtained using PCR amplification and subcloning of PCR products (Fig. 1). The cloned DNA from pFhCP and $\mathrm{pFhCPc}$ was amplified by PCR using universal primers and the products were sequenced. These plasmids were used for all protein expression experiments.

Proteins present in extracts from Sf9 cells infected with non-recombinant baculoviruses or from Sf9 cells infected with a recombinant one containing either the $\mathrm{hCP}$ or $\mathrm{hCPc}$ constructs were fractionated by SDS/PAGE. Staining with Coomassie brilliant blue showed a polypeptide of about $27 \mathrm{kDa}$ in cells infected with BhCP and of about $28 \mathrm{kDa}$ in cells infected with $\mathrm{BhCPc}$, that were not present in cells infected by non-recombinant baculovirus (Fig. 2).

In immunoblotting experiments two major polypeptides of $27 \mathrm{kDa}$ for the $\mathrm{BhCP}$ recombinant and $28 \mathrm{kDa}$ for the $\mathrm{BhCPc}$ recombinant, corresponding to the Coomassie-stained bands, were detected. Additional polypeptides of about $24 \mathrm{kDa}$ and $25 \mathrm{kDa}$ appeared for $\mathrm{hCP}$ and $\mathrm{hCPc}$, respectively, probably as a result of protease activity in insect cells (Fig. 3).

A fraction of soluble proteins carrying VLPs from recombinant baculoviruses $\mathrm{BhCP}$ and $\mathrm{BhCPC}$ and similarly prepared proteins from non-recombinant baculovirus were treated with DNase I and RNase A. After extraction the remaining nucleic acids were separated on $1.5 \%$ agarose (Fig. 4). It was shown that small heterologous nucleic acids were protected in the presence of the modified coat proteins of PLRV. The size of the putatively encapsidated nucleic acids is rather small and lies between the size of tRNA and the size of a single-stranded RNA of 200 nucleotides.

Our preliminary results show that the coat protein of potato leafroll virus is a good candidate for further experiments leading to the engineering of native or modified virus-like particles which could protect or encapsidate small nucleic acids. Additional in vitro assembly studies on PLRV VLPs will be 
RNA of PLRV

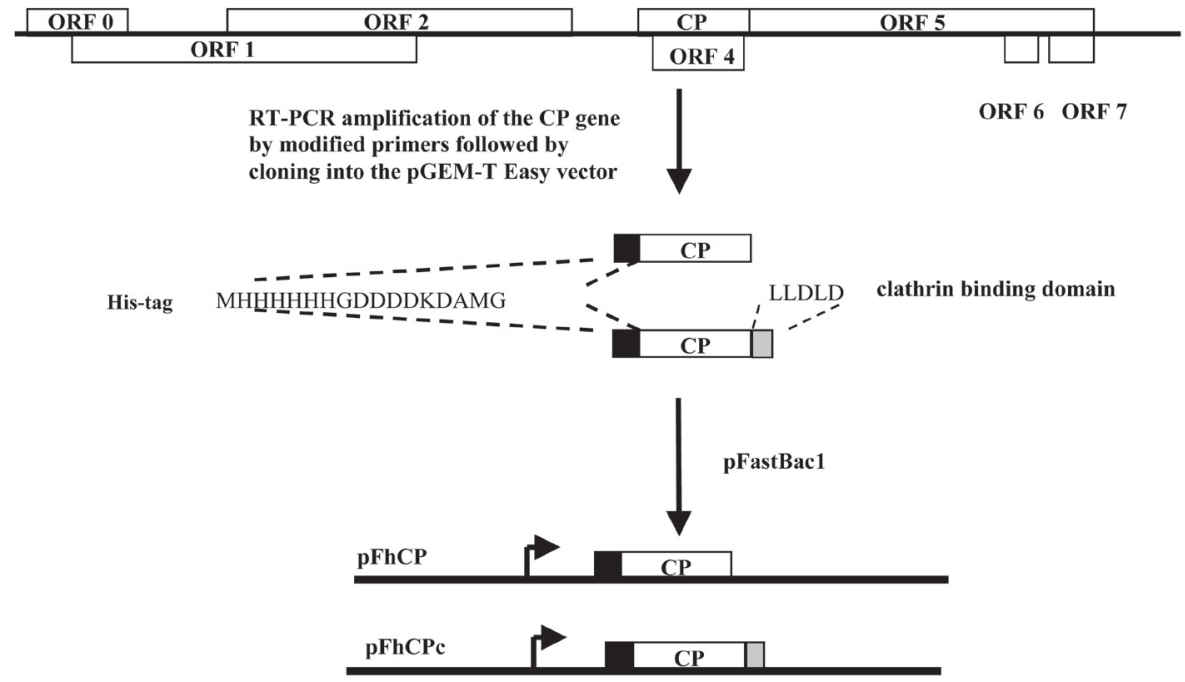

Figure 1. Scheme of cloning of the PLRV CP gene and construction of donor FastBac plasmids.

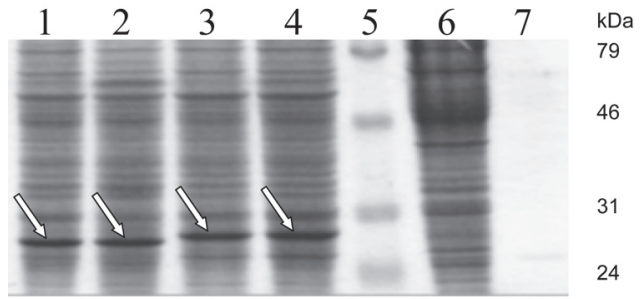

Figure 2. SDS/PAGE of proteins from Sf9 cels. Lane 1, cells infected with BhCP after $72 \mathrm{~h}$; lane 2, cells infected with BhCP after $96 \mathrm{~h}$; lane 3, cells infected with BhCPc after $72 \mathrm{~h}$; lane 4, cells infected with BhCPc after $96 \mathrm{~h}$; lane 5, prestained molecular mass marker (Fermentas), lane 6, cells infected with non-recombinant baculovirus; lane 7, CP of PLRV. Arrows indicate the infectionspecific polypeptides. The gel was stained with Coomassie brilliant blue.

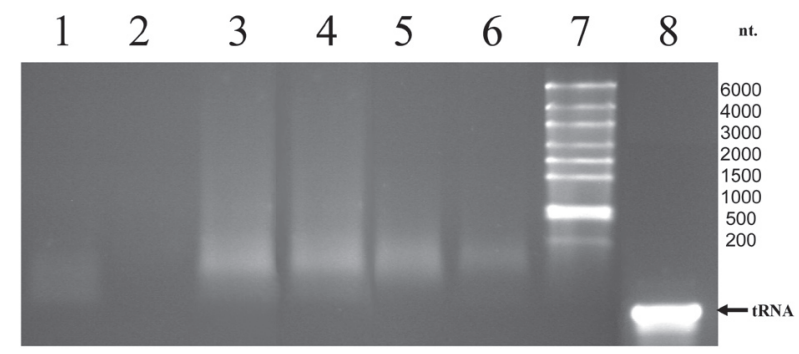

Figure 4. Non-denaturing $1.5 \%$ agarose gel with nucleic acids derived from PLRV VLPs treated with DNase I and RNase $\mathrm{A}$ for $1 \mathrm{~h}$ at $37^{\circ} \mathrm{C}$.

Lanes 1 and 2, cells collected after 72 and $96 \mathrm{~h}$ after infection with non-recombinat baculovirus; lanes 3 and 4 , cells collected 72 and $96 \mathrm{~h}$ after infection with BhCP; lanes 5 and 6, cells collected 72 and $96 \mathrm{~h}$ after infection with BhCPc; lane 7, RNA Ladder High Range (Fermentas) 0.2, 0.5, $1.0,1.5,2.0,3.0,4.0$ and $6.0 \mathrm{~kb}$; lane 8 , yeast tRNA.

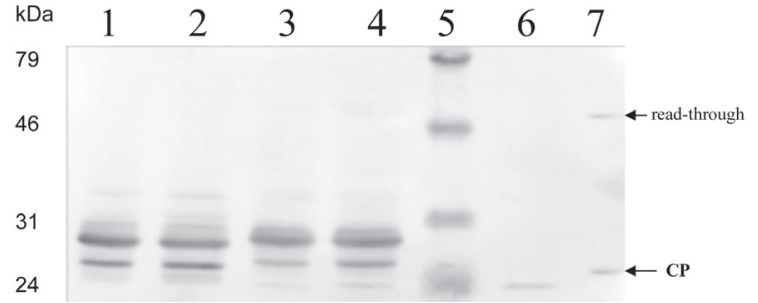

Figure 3. Immunoblotting of proteins from Sf9 cels. Lane 1, cells infected with BhCP after $72 \mathrm{~h}$; lane 2, cells infected with BhCP after $96 \mathrm{~h}$; lane 3, cells infected with BhCPc after $72 \mathrm{~h}$; lane 4, cells infected with BhCPc after $96 \mathrm{~h}$; lane 5, prestained molecular mass marker (Fermentas), lane 6, cells infected with non-recombinant baculovirus; lane $7, \mathrm{CP}$ of PLRV. Anti-PLRV antibodies linked to alkaline phosphatase were visualized by the NBT/BCIP assay.

focused on encapsidation of nucleic acids like oligonucleotides, PNA or siRNA.

\section{Acknowledgements}

This work was supported by a mini grant SBM 07 funded by the Warsaw School of Molecular Biology, PhD studies at the Institute of Biochemistry and Biophysics, to E.S.

\section{REFERENCES}

Ausubel FM, Brent R, Kingston RE, Moore DD, Seidman JG, Smith J, Struhl K (1987) Western Blotting. In Current Protocols in Molecular Biology. Ausubel FM, ed, pp 10.8.1-10.8.6. Green Publishing Associates and WileyInterscience, New York. 
Bahner I, Lamb J, Mayo MA, Hay RT (1990) Expression of the genome of potato leafroll virus: readthrough of the coat protein termination codon in vivo. J Gen Virol 71: 2251-2256.

Lamb JW, Duncan GH, Reavy B, Gildow FE, Mayo MA Hay RT (1996) Assembly of virus-like particles in insect cells infected with a baculovirus containing a modified coat protein gene of potato leafroll luteovirus. J Gen $\mathrm{Vi}$ rol 77: 1349-1358.

Mayo MA, Robinson DJ, Jolly CA, Hyman L (1989) Nucleotide sequence of potato leafroll luteovirus RNA. J Gen Virol 70: 1037-1051.
Palucha A, Sadowy E, Kujawa A, Juszczuk M, Zagorski W, Hulanicka D (1994) Nucleotide sequence of RNA of a Polish isolate of potato leafroll luteovirus. Acta Biochim Polon 41: 405-414.

van der Wilk F, Huisman MJ, Cornelissen BJ, Huttinga $H$, Goldbach R (1989) Nucleotide sequence and organization of potato leafroll virus genomic RNA. FEBS Lett 245: 51-66. 